\title{
Spatial variation in porosity and permeability of the Rupel Clay Member in the Netherlands
}

\author{
Hanneke Verweij ${ }^{1, *}$, Geert-Jan Vis ${ }^{1}$ \& Elke Imberechts ${ }^{2}$
}

1 TN0, Princetonlaan 6, 3584 CB Utrecht, The Netherlands

2 Advison, Klein Vuurgatstraat 7, 1560 Hoeilaart, Belgium

* Corresponding author. Email: hanneke.verweij@tno.nl

Manuscript received: 24 July 2015, accepted: 16 June 2016

\section{Abstract}

The spatial distribution of porosity and permeability of the Rupel Clay Member is of key importance to evaluate the spatial variation of its sealing capacity and groundwater flow condition. There are only a limited number of measured porosity and permeability data of the Rupel Clay Member in the onshore Netherlands and these data are restricted to shallow depths in the order of tens of metres below surface. Grain sizes measured by laser diffraction and SediGraph ${ }^{\circledR}$ in samples of the Rupel Clay Member taken from boreholes spread across the country were used to generate new porosity and permeability data for the Rupel Clay Member located at greater burial depth. Effective stress and clay content are important parameters in the applied grain-size based calculations of porosity and permeability.

The calculation method was first tested on measured data of the Belgian Boom Clay. The test results showed good agreement between calculated permeability and measured hydraulic conductivity for depths exceeding $200 \mathrm{~m}$.

The spatial variation in lithology, heterogeneity and also burial depth of the Rupel Clay Member in the Netherlands are apparent in the variation of the calculated permeability. The samples from the north of the country consist almost entirely of muds and as a consequence show little lithology-related variation in permeability. The vertical variation in permeability in the more heterogeneous Rupel Clay Member in the southern and east-southeastern part of the country can reach several orders of magnitude due to increased permeability of the coarser-grained layers.

Keywords: permeability, porosity, Rupel Clay

\section{Introduction}

Quantitative knowledge of the subsurface is a prerequisite for assessing and understanding its storage and energy resource potential, resource producibility and environmental impact. Finegrained sedimentary rocks such as the Rupel Clay Member may be barriers for fluid flow, where fluids include water, oil or gas. Porosity and permeability are of key importance in this respect. The focus of this paper is on porosity and, especially, permeability of the Rupel Clay Member. The Oligocene Rupel Clay Member (also known as Boom Clay) is part of the Rupel Formation. The current burial depth of the Rupel Clay Member varies from close to the surface to about $1500 \mathrm{~m}$ (Fig. 1; Vis et al., 2016). The marine sediments of the Rupel Formation were deposited in the southern part of the North Sea Basin. The formation includes three members, from bottom to top: the sandy Vessem
Member, Rupel Clay Member and sandy Steensel Member. The Rupel Clay Member consists of clays that become more silty towards the base and top of the Member. Vis et al. (2016) provide a detailed description of the Rupel Clay Member based on new grain-size analysis data, and interpretation thereof in relation to the geological setting of the Rupel. Texturally, the Rupel Clay Member includes muds, sandy muds and to a lesser extent muddy sands. Vis et al. demonstrate that the Rupel Clay Member shows a spatial variation in lithological composition related to the depositional environment of the sediments: sediments are generally finer-grained and show less vertical variation in the northern Dutch onshore corresponding to a more distal part of the palaeo basin and are coarser-grained and show more vertical heterogeneity in the southern and eastern onshore corresponding to the palaeo basin margin. They subdivide the member into three subunits based on grain-size characteristics: the lower 


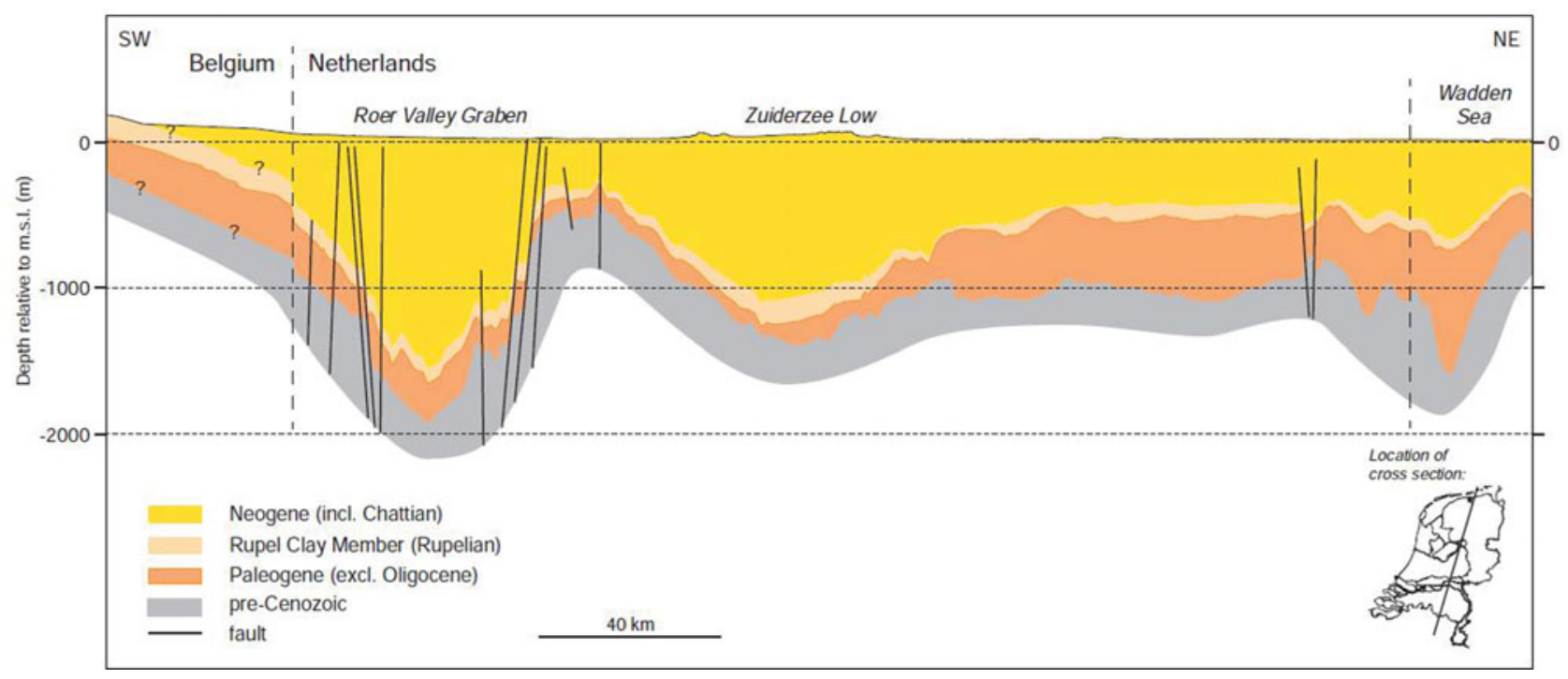

Fig. 1. North-south cross-section showing the variation in burial depth of the Rupel Clay Member (from Vis et al., 2016).

subunit shows a fining upward trend, the middle subunit is finest-grained and the upper subunit shows a coarsening upward trend.

Porosity and permeability or hydraulic conductivity measurements of the Rupel Clay Member in the subsurface of the onshore Netherlands are limited and these measurements are restricted to shallow depths in the order of tens of metres below surface (Rijkers et al., 1998; Wildenborg et al., 2000; Vis \& Verweij, 2014). In the northwestern part of Belgium, however, the Boom Clay has been studied extensively for more than 30 years, especially at the Mol investigation site (the High-Activity Disposal Experiment (HADES) underground research facility), which has been constructed in the middle part of the Boom Clay at $223 \mathrm{~m}$ depth (Yu et al., 2013). Clay samples from boreholes at Mol and other locations in NW Belgium were used for hydraulic conductivity measurement through laboratory experiments, and in situ tests were performed to determine the hydraulic conductivity under undisturbed conditions (Wemaere et al., 2008; Yu et al., 2011).

The grain sizes measured in samples of the Rupel Clay Member taken from boreholes spread across the Netherlands (Fig. 2; Vis et al., 2016) were used to generate new porosity and permeability data for the Rupel Clay Member located at greater burial depth. The published measured hydraulic conductivity data from the Belgium Boom Clay could be used to test and select appropriate input parameters for the grain-size based calculation methods.

\section{Factors influencing mud porosity and permeability}

Muds mostly comprise sediments of fraction $<63 \mu \mathrm{m}$, i.e. mostly consisting of a clay fraction $(<2 \mu \mathrm{m})$ and a silt fraction $(2 \mu \mathrm{m}-$
$<63 \mu \mathrm{m})$. In general, depositional porosities of muds are high, the more so for the clay-rich muds, reaching magnitudes of 80$90 \%$ (e.g. Aplin \& Macquaker, 2011). Porosity decreases with increasing burial depth. At shallow depths of $<2 \mathrm{~km}$ (at temperatures $<70^{\circ} \mathrm{C}$ ) porosity reduction is mainly due to mechanical compaction driven by the increase of effective stress. Compressibility of mud, and therefore its rate of compaction, is strongly influenced by grain size: finer-grained muds have higher depositional porosities, but their rate of compaction is higher (Yang \& Aplin, 2004; Aplin \& Macquaker, 2011). In addition, clay mineralogy influences compressibility and compaction. For example, Mondol et al. (2007) demonstrated with experimental mechanical compaction of clay mineral aggregates that coarsegrained kaolinite is more compressible than finer-grained smectite. The clay mineralogy of the Rupel Clay Member consists of a suite of different clays, including kaolinite, smectite, illite and interstratified clay minerals (Koenen \& Griffioen, 2014). At a certain porosity, clay-rich mudstones have smaller pore sizes than silt-rich mudstones (Schlömer \& Krooss, 1997; Dewhurst et al., 1998, 1999).

Permeability closely relates to pore size and pore-size distribution. Schneider et al. (2011) showed that mudstone permeability increases with a decrease in clay fraction due to the development of a dual-porosity system, where large pore throats between silt grains that act as high-permeability pathways are preserved in addition to small pores within the clay matrix. Just like porosity, permeability of mudstones is also strongly controlled by their grain size, grain-size distribution, and mineralogy. At a given porosity, vertical permeabilities vary over orders of magnitude (Neuzil, 1994; Reece et al., 2012; Casey et al., 2013), while clay-rich mudstones have lower permeabilities than clay-poor ones. This porosity-permeability relation as a function of clay content in fine-grained sediments is consistent with findings of Daigle \& Screaton (2015). 


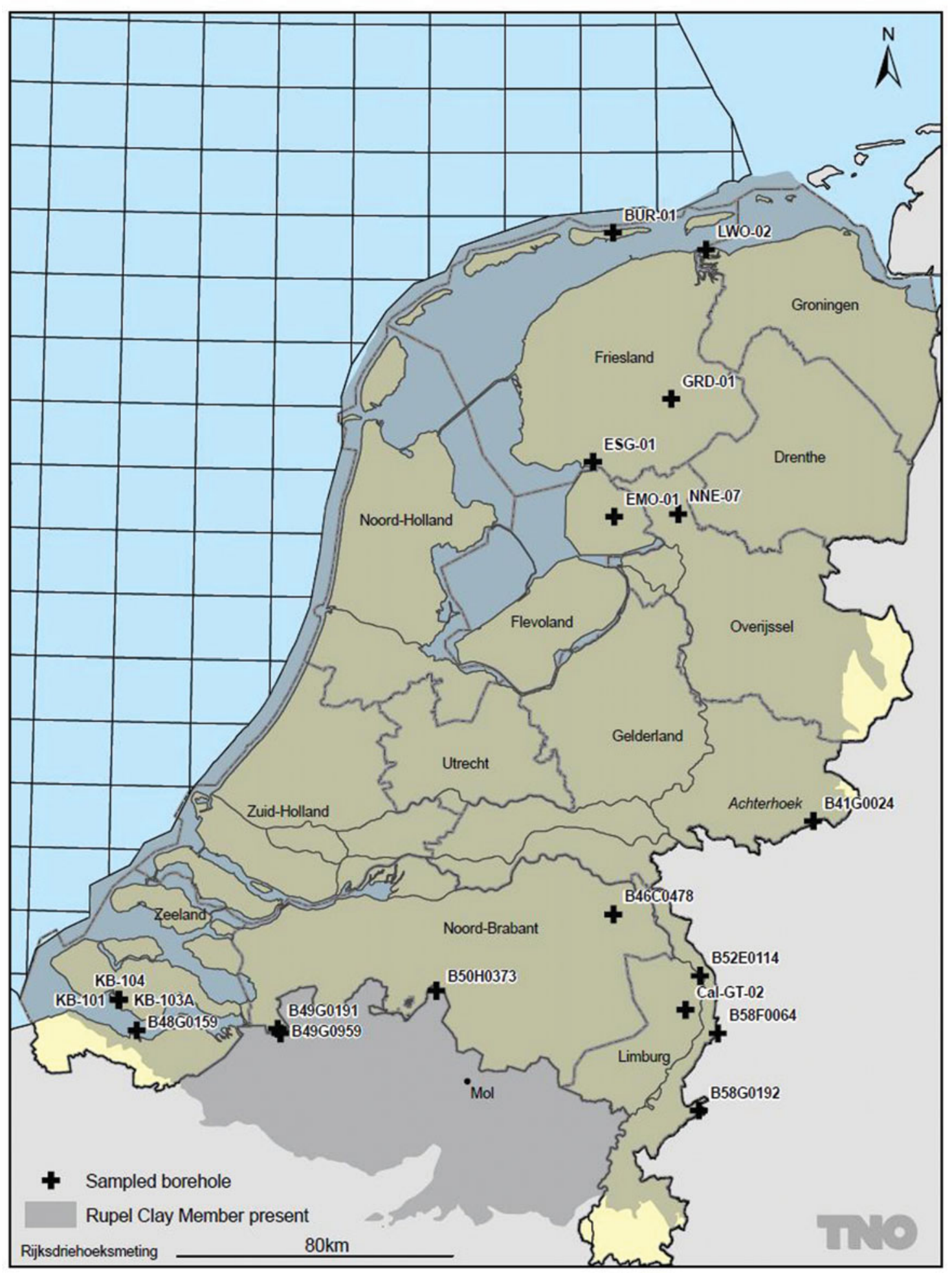

Fig. 2. Location of sampled boreholes for grain-size analysis in the Netherlands. The following sampled boreholes were used to calculate porosity and permeability: northern area (BUR-01, LWO-02, GRD-01, ESG-01, EMO-01, NNE-07); southwest and western area (B48G0159, B49G0191, B49G0959, B50H0373); and eastern and southeastern area (B41G0024, B46C0478, B52E0114).

\section{Database}

Grain-size measurements from 107 samples of the Rupel Clay Member from 13 boreholes in the Netherlands were used to calculate porosity and permeability. The boreholes are listed in Tables 1-3 in Appendix 1, and Figure 2 shows the location of the boreholes. The sampling and grain-size measurement procedures are described in Vis et al. (2016). Grain size was 


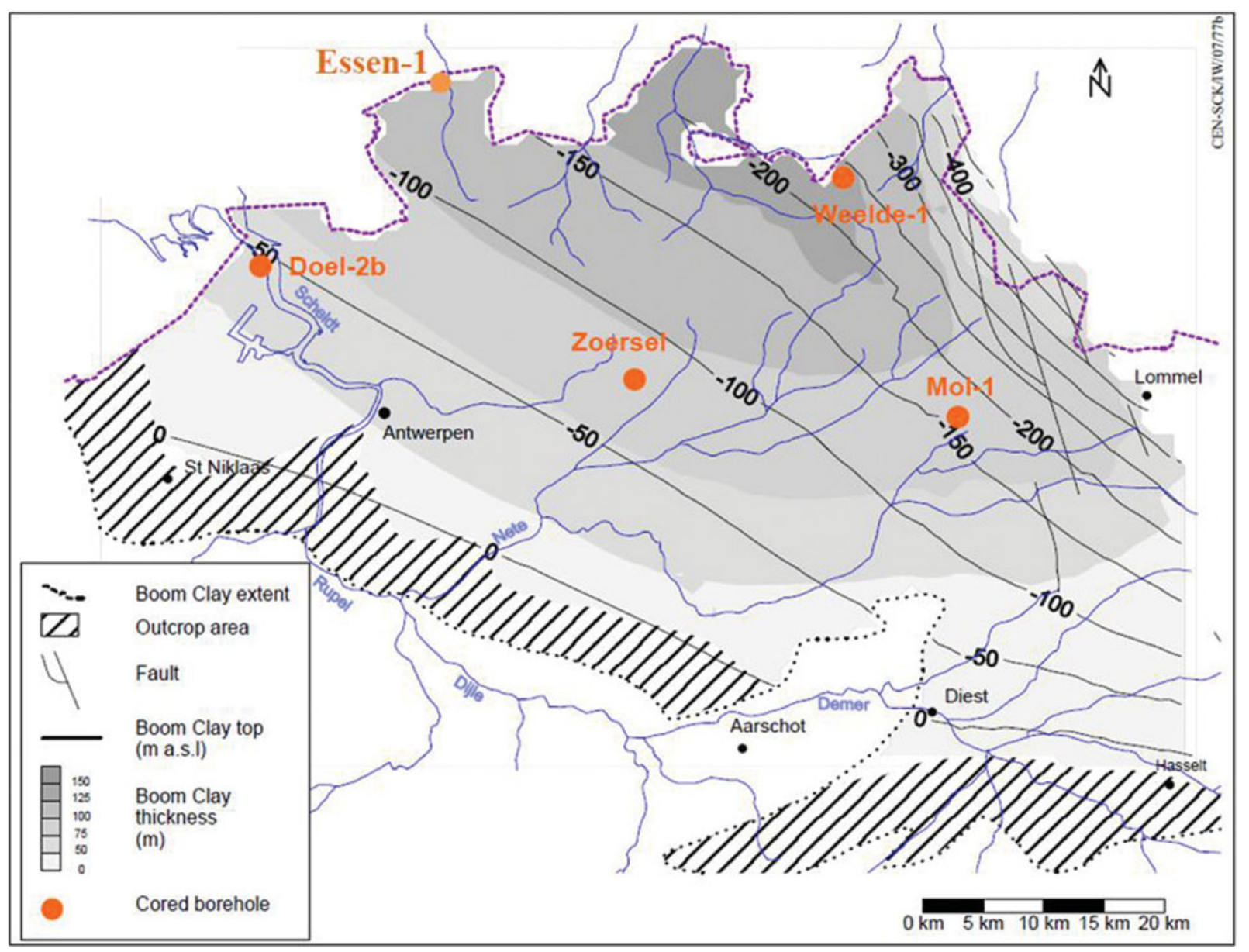

Fig. 3. Location of sampled boreholes and distribution of the 'Boom Clay' in NW Belgium (from Yu et al., 2013, after Wemaere et al., 2008).

measured by Qmineral bvba in Belgium (www.qmineral.com), using both laser diffraction (low-angle laser light scattering) and SediGraph ${ }^{\circledR}$ (X-ray measurements). The Excel spreadsheet program GRADISTAT8 (Blott \& Pye, 2001) was used to analyse the measured grain-size data (Vis et al., 2016). The grain-size measurements of the Rupel Clay Member carried out by two different methods provided the opportunity to compare the clay size measurements of both methods.

Published measured hydraulic conductivity and grain-size data of the Boom Clay at four borehole locations (Mol-01, Zoersel, Weelde-01, Doel-2b) in Belgium (Yu et al., 2011) were used to test the grain-size based method for calculating porosity and permeability. Figure 3 shows the location of these boreholes.

\section{Methodology}

Luijendijk \& Gleeson (2015) provided an overview and comparison of grain-size based equations to calculate porosity and permeability developed for sand-clay mixtures using experimental and field datasets. The grain-size based equations discussed are not exclusively for application to muds (grain-size fraction mostly $<63 \mu \mathrm{m}$ and sand content $<10 \%$ ). Yang \& Aplin (2004, 2010) developed equations specially designed to calculate mud porosity and vertical permeability, respectively. These equations were selected to calculate porosity and vertical permeability using the grain-size analysis data from mud samples derived from the Rupel Clay Member. Yang \& Aplin (2004) used mudstone samples from the North Sea and Gulf of Mexico to describe the mechanical compaction and associated decrease in porosity of mudstones. The relatively shallow sampling depths of the Rupel Clay Member in the Netherlands (21-672 mTVDss (metres true vertical depth below ground surface)) are well within the realm of mechanical compaction. The porosity-permeability equation of Yang \& Aplin (2010) was used to calculate permeability. Yang \& Aplin derived their permeability equation based mainly on marine mudstones, using more than 300 samples, most of them from the North Sea and Gulf of Mexico. The Yang \& Aplin $(2004,2010)$ equations include clay content and effective stress as important parameters.

In order to test the applicability of the calculation method for the Rupel Clay Member, we compared the permeability based on measured hydraulic conductivity of the Belgian Boom Clay at four borehole locations (Yu et al., 2011) with the calculated permeability using the Yang \& Aplin (2004, 2010) 
Doel 2b

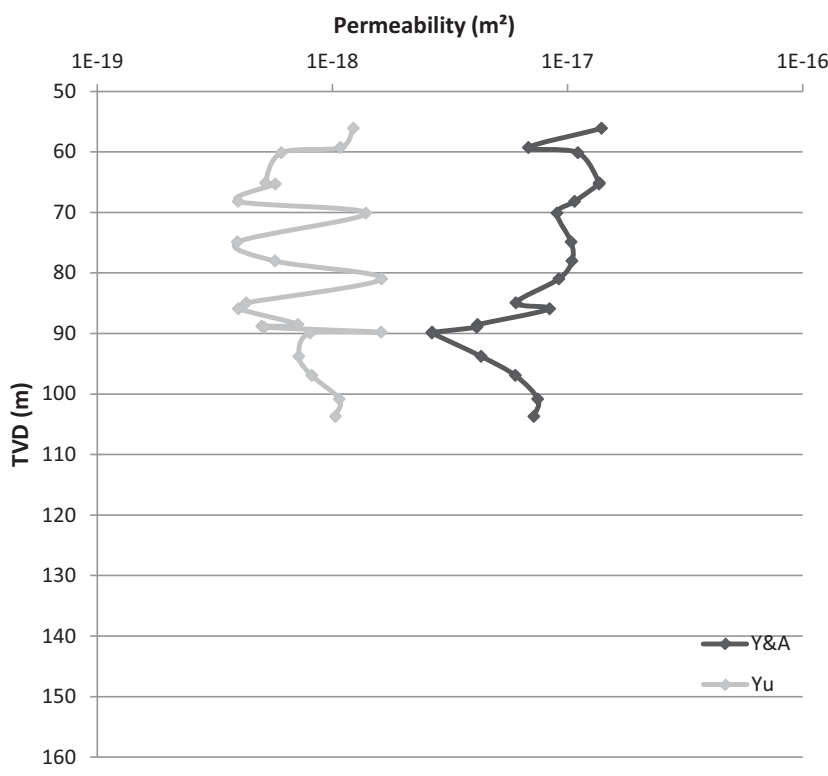

Mol-01

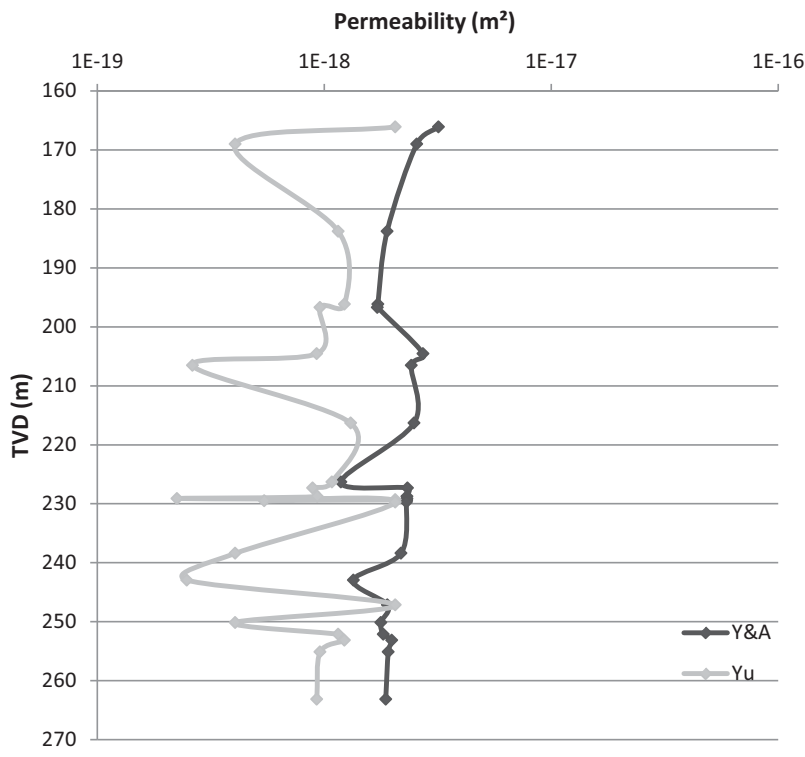

Zoersel

Permeability $\left(\mathrm{m}^{2}\right)$

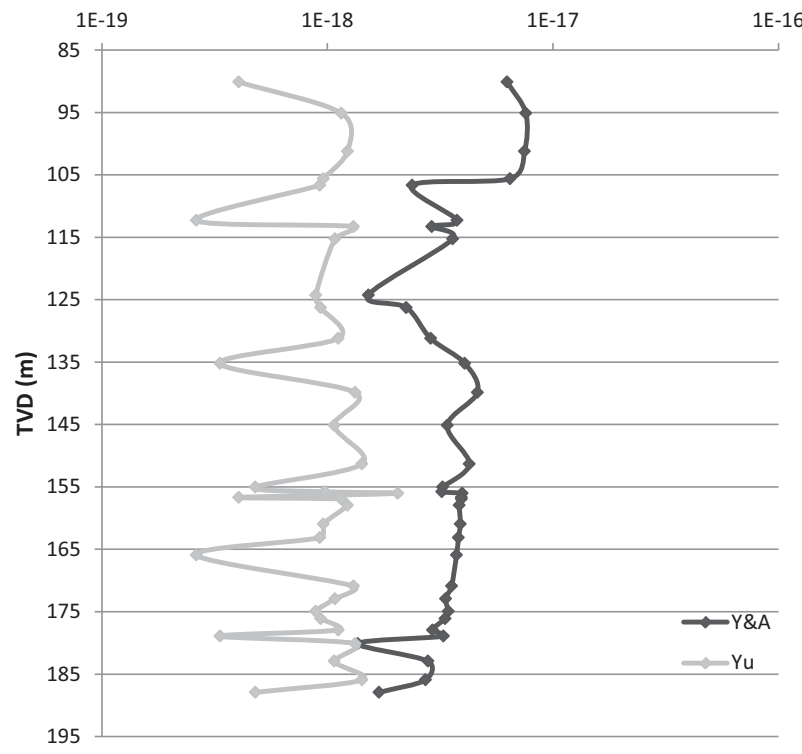

Weelde-01

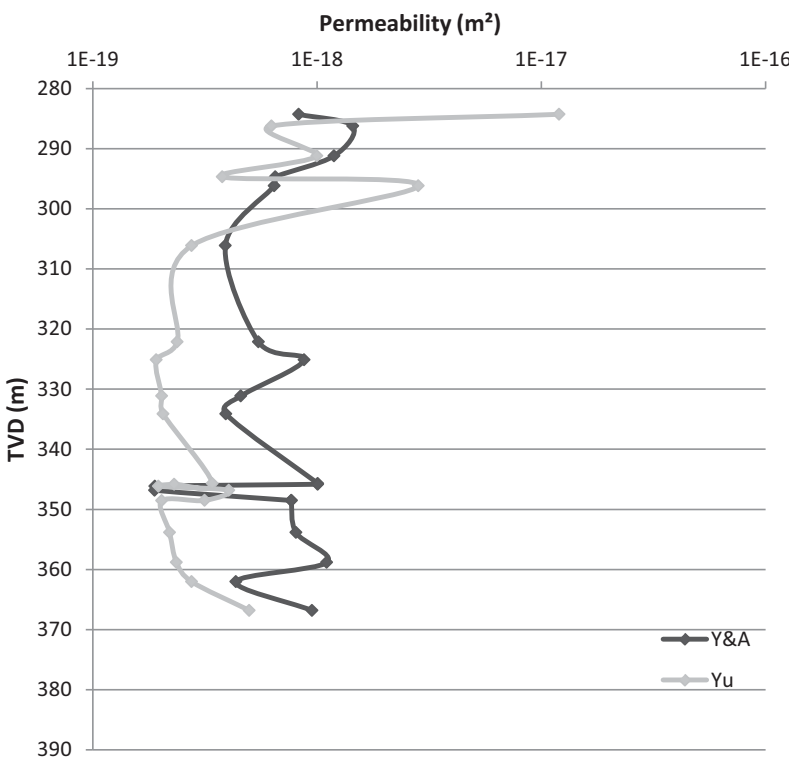

Fig. 4. Cross plots showing measured and calculated permeability of the 'Boom Clay' versus depth at four borehole locations in NW Belgium (see Fig. 3 for location of the boreholes) (modified after Imberechts, 2014 and Verweij et al., 2014). Published measured hydraulic conductivity and grain-size data of the Boom Clay (Yu et al., 2011) were used to derive the measured vertical permeability ('Yu') and the calculated vertical permeability ('Y \& $\left.A^{\prime}\right)$, respectively.

equations for published measured clay size data from the Boom Clay (Yu et al., 2011) (Fig. 4). Figure 4 shows that the difference between calculated and measured permeability decreases with depth. The largest difference is observed for samples from Doel$2 \mathrm{~b}$ from depths of $<100 \mathrm{~m}$. At depths exceeding $200 \mathrm{~m}$ there is a slight overestimation of permeability of less than one order of magnitude.

The clay content is a very important input parameter in the equations. As stated above, the grain sizes of the Rupel Clay
Member were measured by two different methods (laser diffraction and Sedigraph). The results with respect to clay percentage were found to vary strongly depending on the measurement and analysis technique used (Vis et al., 2016). According to Konert $\&$ Vandenberghe (1997), the $<8 \mu \mathrm{m}$ grain-size fraction defined by laser techniques corresponds to a grain size of $<2 \mu \mathrm{m}$ defined by classical pipette analysis. They proposed to use the measured fraction smaller than $8 \mu \mathrm{m}$ (using laser diffraction) as representing the clay fraction, i.e. representing a grain size 

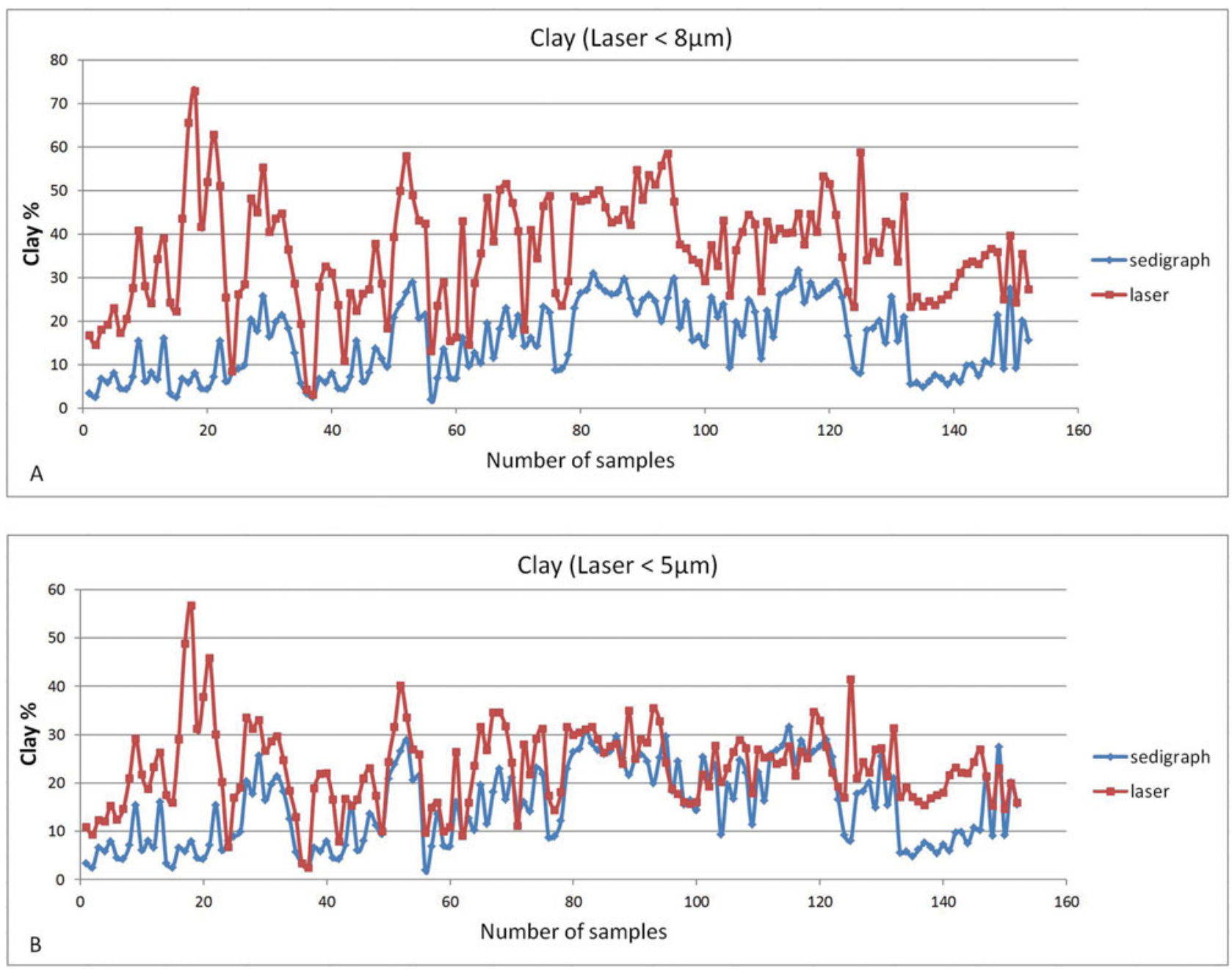

Fig. 5. (A) Comparison of grain-size fraction of $<8 \mu \mathrm{m}$ resulting from laser diffraction measurements with the standard grain size for clay ( $<2 \mu \mathrm{m})$ measured with the Sedigraph. (B) Comparison of grain-size fraction of $<5 \mu \mathrm{m}$ resulting from laser diffraction measurements with the standard grain size for clay $(<2 \mu \mathrm{m})$ measured with the Sedigraph. (From Imberechts, 2014.)

smaller than $2 \mu \mathrm{m}$. Based on grain-size measurements of 146 samples from the Rupel Clay Member at 17 borehole locations, Imberechts (2014) investigated which grain size measured with the laser diffraction method corresponds best with the clay fraction of the Rupel Clay Member determined with the Sedigraph. Different grain-size fractions of the laser diffraction measurements, ranging from 2 to $8 \mu \mathrm{m}$, plotted together with the standard clay grain size of $2 \mu \mathrm{m}$ of the Sedigraph measurements, showed that the best agreement was found for laser diffraction grain-size measurement of $5 \mu \mathrm{m}$ and a Sedigraph measurement of $2 \mu \mathrm{m}$ (Fig. 5). Figure 5 shows that the laser grain-size fraction $<8 \mu \mathrm{m}$ overestimates the Sedigraph clay fraction of $2 \mu \mathrm{m}$. Imberechts also compared porosity and permeability calculations using Sedigraph clay \% $(<2 \mu \mathrm{m}$ with laser clay $\%<5 \mu \mathrm{m}$ and laser clay $\%<8 \mu \mathrm{m}$. The cross plots of calculated porosity and permeability vs depth for the different boreholes showed that in general the porosity and permeability decreases with depth for the Sedigraph and the two laser clay fractions, and that only for about $50 \%$ of the boreholes does the laser clay $\%<5 \mu \mathrm{m}$ show a better fit with the Sedigraph clay $\%<2 \mu \mathrm{m}$.

The calculation of the porosity and permeability, using the Yang \& Aplin $(2004,2010)$ equations was applied to those samples of the Rupel Clay Member that are texturally characterised as mud.

Given the results of Imberechts (2014) and published variations in the measured clay percentages depending on the technique used (Konert \& Vandenberghe, 1997; Buurman et al., 2001; Vis et al., 2016), we performed the calculation of porosity and permeability of the mud samples for the following 'clay fraction' measured by laser diffraction and analysed by GRADISTAT8 software (Blott \& Pye, 2001), i.e. fraction of grain size $<8 \mu \mathrm{m}$ (corresponding to laser-measured fraction of clay + very fine silt + fine silt). The laser diffraction measurements were selected because laser diffraction is the most used method for measuring grain sizes in the Netherlands and calculations based on these measurements allow more direct comparison with older and future permeability calculations. 
The porosity and permeability for samples characterised as sandy mud or muddy sand were calculated by conventional lithology-dependent porosity-depth and porosity-permeability relations. The porosity equation is a porosity-depth relation for mechanical compaction based on the conventional Athy's law, and the applied porosity-permeability relation is the multipoint model (Hantschel \& Kauerauf, 2009).

\section{Results}

The results of the porosity and permeability calculations are presented in Appendix 1 and Figure 6. The vertical permeability values of the mud part of the Rupel Clay Member at depths of $>400 \mathrm{~m}$ are all in the range of $10^{-19} \mathrm{~m}^{2}$ (corresponding to a vertical hydraulic conductivity of $10^{-12} \mathrm{~m} \mathrm{~s}^{-1}$ ).

The spatial variation in lithological composition of the Rupel Clay Member is reflected in variation in its permeability. Samples of the boreholes in the northern part of the Netherlands (LW0-02, GRD-01, EM0-01; and seven out of eight samples of ESG-01) are all muds and show the least vertical variation in permeability (Fig. 6). For example, the vertical permeability of the Rupel Clay Member in GRD-01 varies between 5.0E-19 and $6.9 \mathrm{E}-19 \mathrm{~m}^{2}$ over a depth interval of $448-569 \mathrm{~m}$. The four low permeability outliers for their depth of measurement (Fig. 6) are associated with a high clay content of about $55-70 \%$. In both the east-southeastern and the southwest-southern areas the 'mud' part of the Rupel Clay Member is overlain and/or underlain by coarser-grained sediments: the vertical variation in permeability over the Rupel Clay Member reflects this heterogeneity (Fig. 6). For example, the vertical permeability of the Rupel Clay Member in B52E0114 (east-southeastern area) varies between $4.6 \mathrm{E}-14 \mathrm{~m}^{2}$ and $1.6 \mathrm{E}-19 \mathrm{~m}^{2}$ over a depth interval $381-524 \mathrm{~m}$, and that in $\mathrm{B} 50 \mathrm{H} 0373$ (southern area) varies between $6.0 \mathrm{E}-17 \mathrm{~m}^{2}$ and $7.4 \mathrm{E}-19 \mathrm{~m}^{2}$ over a depth interval of $325-470 \mathrm{~m}$. The highest permeability for the depth of measurement is related to very high sand contents: for example, the two samples with highest permeability have sand contents of 76.3 and $82.2 \%$. It should be realised by comparing permeability of muds and coarser-grained textures, that different calculation methods were used to estimate the permeability of the mud and the coarser-grained muddy-sand and sandy-mud parts of the Rupel Clay Member.

Spatial variation in the calculated vertical permeability of the Rupel Clay Member also reflects differences in its burial depth in addition to differences in lithology (Fig. 6). The calculated permeability for the samples in the southwest and southern area also clearly shows this influence. The calculated vertical permeability for mud samples decreases from 7.7E-17 $\mathrm{m}^{2}$ at a very shallow depth of $21 \mathrm{~m}$ (B48G0159), 1.2E-17 m² (B49G0191; $82 \mathrm{~m}), 5.8 \mathrm{E}-18 \mathrm{~m}^{2}$ (B49G0959; $\left.129 \mathrm{~m}\right)$, to $9.2 \mathrm{E}-19 \mathrm{~m}^{2}$ at $442 \mathrm{~m}$ (B50H0373).

\section{Discussion}

There are a number of uncertainties involved in the application of the Yang \& Aplin (2004, 2010) equations for calculating porosity and permeability of the mud part of the Rupel Clay Member:

- An important uncertainty concerns the clay content to be used. The two methods, laser diffraction and Sedigraph, that were used to measure grain sizes of the samples produce different results for the clay content. Several authors have shown that clay content is underestimated by the laserdiffraction method (Konert \& Vandenberghe, 1997; Buurman et al., 2001). This is confirmed by the present study. There is, however, uncertainty about the magnitude of the underestimation. Here we followed Konert \& Vandenberghe (1997) and used clay $<8 \mu$ m measured by laser diffraction.

- The permeability model of Yang \& Aplin (2010) is based on the assumption of homogeneity of the mud sample. The spatial lithological heterogeneity in muds at $\mathrm{cm}$ to $\mathrm{m}$ scale is not taken into account in the model. Heterogeneity at this scale also affects the pore size distribution and as a consequence its permeability to a greater or lesser extent (Hildenbrand, 2003; Drews, 2012; Hemes et al., 2013). Heterogeneity at this scale occurs in the Rupel Clay Member, especially in the southern and eastern parts of the country. In this study the vertical permeability was calculated for sample scale only. On a larger scale, the grain-size data and associated permeability showed that the Rupel Clay Member exhibits layering on a member scale. The Rupel Clay Member is probably also anisotropic to a greater or lesser extent. This was also demonstrated by vertical and horizontal hydraulic conductivity measurements performed on the Belgian Boom Clay. The measurements showed that the horizontal conductivity, at formation scale, can be 5-60 times higher than the vertical ones (Wemaere et al., 2008).

- Yang \& Aplin (2010) reported that for their database $(300$ samples of marine mudstones, mostly from the North Sea and Gulf of Mexico) an uncertainty of magnitude in permeability at a given porosity is one order of magnitude. The mud samples from the Rupel Clay Member belong to one system, in contrast to the samples from the Yang \& Aplin (2010) study. It is currently not known if this more homogeneous sample set reduces the uncertainty in calculated permeability for the Dutch mudstones.

- The porosity and permeability has been calculated using effective stress values related to current burial depth. Burial history has not been taken into account. If previous deeper burial of the Rupel Clay has occurred at a certain location, this may have led to overcompaction of the clay. Such a condition is known/expected to occur in the SW of the Netherlands where the Rupel Clay Member is at very shallow depths (Vis et al., 2016). Hitherto no influence of past 


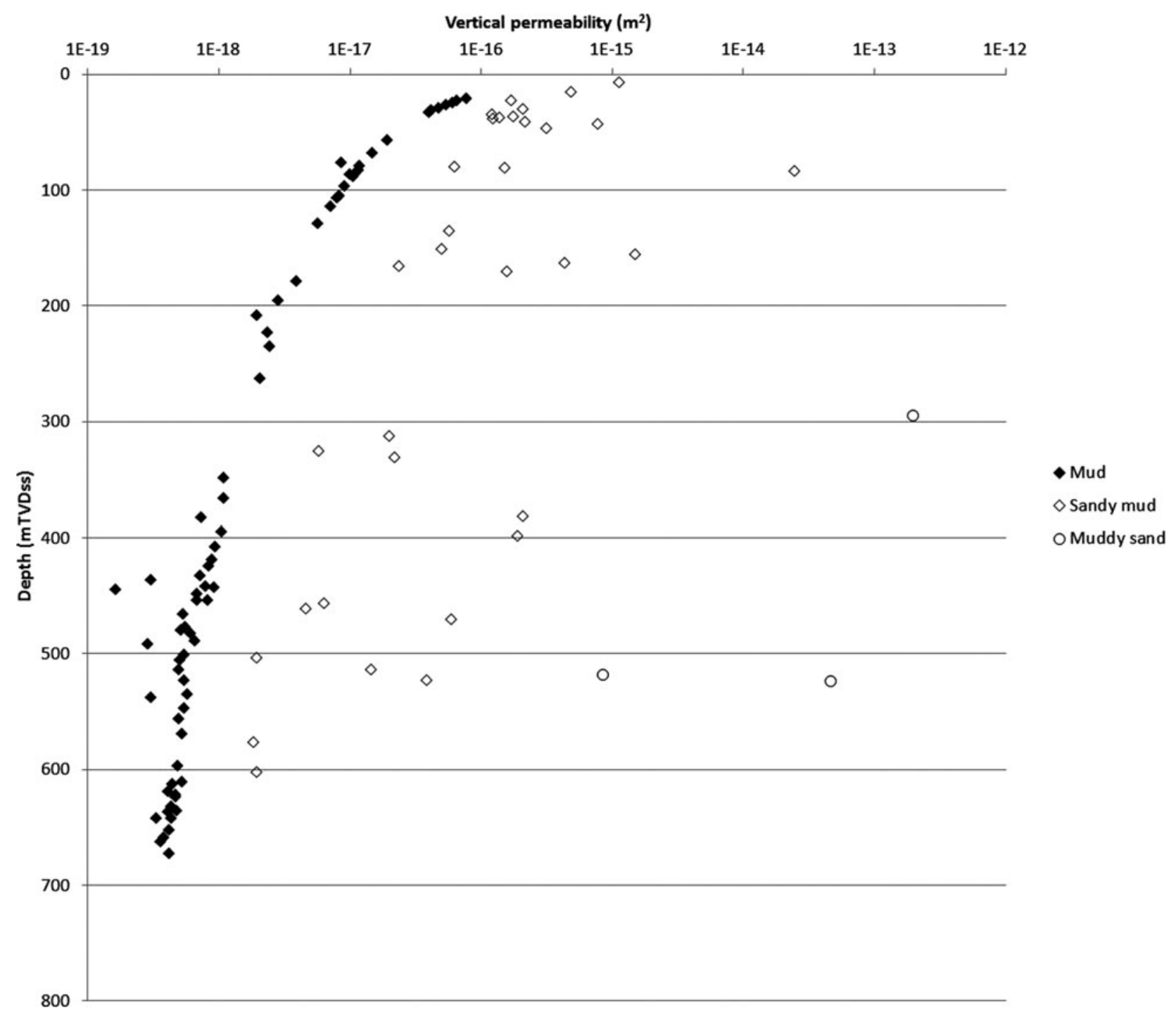

Fig. 6. Cross plot of calculated vertical permeability versus depth for samples of mud, sandy mud and muddy sand of the Rupel Clay Member (see Appendix 1 for the calculated values).

glacial loading has been identified for Paleogene mudrocks in the northern part of the Netherlands (Kooi, 2000).

- The calculation method does not take into account the influence of variation in mineralogy. Koenen \& Griffioen (2014, 2016) analysed samples from the Rupel Clay Member across the Netherlands to characterise geochemistry and mineralogy. They found that the clay mineralogy of the Rupel Clay Member consists of a suite of different clays, including kaolinite, smectite, illite and interstratified clay minerals.

In order to obtain insight into the applicability of the calculation method for the Rupel mud samples, the results of calculations were compared with measured hydraulic conductivity values for the Belgian Boom Clay. This comparison indicated that for a depth of $>200 \mathrm{~m}$ there is a slight overestimation of permeability of less than one order of magnitude. The calcu- lated vertical permeability of the mud part of the Rupel Clay Member in the Netherlands probably also slightly overestimates its real value.

\section{Conclusions}

Comparison of the permeability based on measured hydraulic conductivity of the Belgian Boom Clay at four borehole locations (Yu et al., 2011) with the calculated permeability using the Yang \& Aplin $(2004,2010)$ equations for published measured clay size data from the Boom Clay (Yu et al., 2011) showed that the calculated permeability slightly overestimates measured permeability by less than one order of magnitude for burial depths exceeding $200 \mathrm{~m}$. An important uncertainty in the application of the calculation method concerns the clay content to be used from laser diffraction grain-size measurements. 
The calculated porosity and vertical permeability of the Rupel Clay Member provide, for the first time, insight into these key properties at depths beyond a few tenths of a metre.

The spatial variation in lithology, heterogeneity and also burial depth is apparent in the variation of the calculated vertical permeability using the grain-size analyses of the samples of the Rupel Clay Member. The samples from the north of the country consist almost entirely of muds with calculated vertical permeability of less than $8.3 \mathrm{E}-19 \mathrm{~m}^{2}\left(8.3 \mathrm{E}-12 \mathrm{~m} \mathrm{~s}^{-1}\right)$ (calculated using clay + very fine silt + fine silt \% from laser diffraction measurements). The vertical variation in permeability in the more heterogeneous Rupel Clay Member in the southern and east-southeastern part of the country can reach several orders of magnitude due to increased permeability of the coarsergrained sandy-mud and muddy-sand layers.

\section{Acknowledgements}

The research leading to these results has received funding from the Dutch research programme on geological disposal OPERA. OPERA is financed by the Dutch Ministry of Economic Affairs and the public limited liability company ElektriciteitsProduktiemaatschappij Zuid-Nederland (EPZ) and coordinated by Centrale Organisatie Voor Radioactief Afval (COVRA). We thank the reviewers for comments and suggestions that improved the paper.

\section{References}

Aplin, A.C. \& Macquaker, H., 2011. Mudstone diversity: origin and implications for source, seal, and reservoir properties in petroleum systems. AAPG Bulletin 95(12), 2031-2059.

Blott, S.J. \& Pye, K., 2001. GRADISTAT: a grain size distribution and statistics package for the analysis of unconsolidated sediments. Earth Surface Processes and Landforms 26(11), 1237-1248.

Buurman, P., Pape, Th., Reijneveld, J.A., De Jong, F. \& Van Gelder, E., 2001. Laser-diffraction and pipette-method grain sizing of Dutch sediments: correlations for fine fractions of marine, fluvial, and loess samples. Geologie en Mijnbouw/Netherlands Journal of Geosciences 80(2): 49-57.

Casey, B., Germaine, J.T., Flemings, P.B., Reece, J.S., Gao, B. \& Betts, W., 2013. Liquid limit as a predictor of mudrock permeability. Marine and Petroleum Geology 44: 256-263.

Daigle, H. \& Screaton, E.J., 2015. Evolution of sediment permeability during burial and subduction. Geofluids 15, 84-105.

Dewhurst, D.N., Aplin, A.C., Sarda, J.P. \& Yang, Y., 1998. Compaction-driven evolution of porosity and permeability in natural mudstones: an experimental study. Journal of Geophysical Research 103(B1): 651-661.

Dewhurst, D.N., Aplin, A.C. \& Sarda, J., 1999. Influence of clay fraction on pore-scale properties and hydraulic conductivity of experimentally compacted mudstones. Journal of Geophysical Research 104(B12): 29261-29274.
Drews, M.C., 2012. Modelling stress-dependent effective porosity-permeability relationships of metre-scale heterogeneous mudstones. PhD Thesis. Newcastle University (Newcastle, UK): $358 \mathrm{pp}$.

Hantschel, T. \& Kauerauf, A.I., 2009. Fundamentals of basin and petroleum systems modeling. Springer Verlag (Berlin \& Heidelberg): $476 \mathrm{pp}$.

Hemes, S., Desbois, G., Urai, J.L., De Craen, M. \& Honty, M., 2013. Variations in the morphology of porosity in the Boom Clay Formation: insights from 2D high resolution BIB-SEM imaging and mercury injection porosimetry. Geologie en Mijnbouw/Netherlands Journal of Geosciences 92(4): 275-300.

Hildenbrand, A., 2003. Fluid transport processes in mudstones. PhD Thesis. RWTH Aachen University (Aachen): 137 pp.

Imberechts, E.P., 2014. Capillary and permeability seal capacity of mudstones. MSc Thesis. Earth Structure and Dynamics, Utrecht University (Utrecht): 85 pp.

Koenen, M. \& Griffioen, J., 2014. Mineralogical and geochemical characterization of the Boom Clay in the Netherlands. Report OPERA-PU-TN0521-1: $107 \mathrm{pp}$.

Koenen, M. \& Griffioen, J., 2016. Characterisation of the geochemical heterogeneity of the Rupel Clay Member in the Netherlands. Netherlands Journal of Geosciences, this issue.

Konert, M. \& Vandenberghe, J., 1997. Comparison of laser grain size analysis with pipette and sieve analysis: a solution for the underestimation of the clay fraction. Sedimentology 44: 523-535.

Kooi, H., 2000. Land subsidence due to compaction in the coastal area of The Netherlands: the role of lateral fluid flow and constraints from well-log data. Global and Planetary Change 27: 207-222.

Luijendijk, E. \& Gleeson, T., 2015. How well can we predict permeability in sedimentary basins? Deriving and evaluating porosity-permeability equations for noncemented sand and clay mixtures. Geofluids 15, 67-83.

Mondol, N.H., Bjørlykke, K., Jahren, J. \& Høeg, K., 2007. Experimental mechanical compaction of clay mineral aggregates: changes in physical properties of mudstones during burial. Marine and Petroleum Geology 24: 289-311.

Neuzil, C.E., 1994. How permeable are clays and shales? Water Resources Research 30(2): 145-150.

Reece, J.S., Flemings, P.B., Dugan, B., Long, H. \& Germaine, J.T., 2012. Permeability-porosity relationships of shallow mudstones in the Ursa Basin, northern deep water Gulf of Mexico. Journal of Geophysical Research 117(B12): $13 \mathrm{pp}$.

Rijkers, R.H.B., Huisman, D.J., De Lange, G., Weijers, J.P. \& Witmans-Parker, N., 1998. Inventarisatie geomechanische, geochemische en geohydrologische eigenschappen van Tertiaire kleipakketten - CAR Fase II. NITG-TNO. TNO report NITG 98-90-B: $167 \mathrm{pp}$.

Schlömer, S. \& Krooss, B.M., 1997. Experimental characterization of the hydrocarbon sealing efficiency of cap rocks. Marine and Petroleum Geology 14(5), 565-580.

Schneider, J., Flemings, P.B., Day-Stirrat, R.J. \& Germaine, J.T., 2011. Insights into pore-scale controls on mudstone permeability through resedimentation experiments. Geology, 39(11): 1011-1014.

Verweij, J.M., Daza Cajigal, V., De Bruin, G. \& Geel, K., 2014. Capillary seal capacity of Cenozoic mudstone caprocks of shallow gas occurrences, Dutch offshore. Fourth EAGE Shale Workshop, 6-9 April 2014, Porto, Portugal. Extended abstract. 
Vis, G.J. \& Verweij, J.M., 2014, Geological and geohydrological characterization of the Boom Clay and its overburden. Report OPERA-PU-TN0411: $86 \mathrm{pp}$.

Vis, G.J., Verweij, J.M. \& Koenen, M., 2016. The Rupel Clay Member in the Netherlands; towards a better understanding of its depositional environment. Netherlands Journal of Geosciences, this issue.

Wemaere, I., Marivoet, S. \& Labat, S., 2008. Hydraulic conductivity variability of the Boom Clay in north-east Belgium based on four core drilled boreholes. Physics and Chemistry of the Earth 33 (2008), S24-S36.

Wildenborg, A.F.B., Orlic, B., De Lange, G., De Leeuw, C.S., Zijl, W., Van Weert, F., Veling, E.J.M., De Cock, S., Thimus, J.F., Lehnen-de Rooij, C. \& Den Haan, E.J., 2000. Transport of Radionuclides disposed of in Clay of
Tertiary Origin (TRACTOR). Netherlands Institute of Applied Geoscience TNO - National Geological Survey. TNO report NITG 00-223-B: 223 pp.

Yang, Y. \& Aplin, A.C., 2004. Definition and practical application of mudstone porosity - effective stress relationships. Petroleum Geoscience 10: 153-162.

Yang, Y. \& Aplin, A.C., 2010. A permeability-porosity relationship for mudstones. Marine and Petroleum Geology 27: 1692-1697.

Yu, L., Gedeon, M., Wemaere, I., Marivoet, J. \& De Craen, M., 2011. Boom Clay Hydraulic Conductivity - a synthesis of 30 years of research. External report. Belgian Nuclear Research Centre, SCK•CEN-ER-122: 101 pp.

Yu, L., Rogiers, B., Gedeon, M., Marivoet, J., De Craen, M. \& Mallants, D., 2013. A critical review of laboratory and in-situ hydraulic conductivity measurements for the Boom Clay in Belgium. Applied Clay Science 75-76, 1-12. 
Table 1. Calculated porosity and vertical permeability of the Rupel Clay Member in the northern area. Figure 2 shows the borehole locations.

NORTHERN AREA

\begin{tabular}{|c|c|c|c|c|c|c|c|c|c|c|c|c|}
\hline Well name & $\begin{array}{l}\text { Top NMFRC }^{a} \\
\text { (mTVDss) }^{a}\end{array}$ & $\begin{array}{l}\text { Bottom NMFRC }^{\mathrm{a}} \\
\text { (mTVDss) }^{\mathrm{b}}\end{array}$ & $\begin{array}{l}\text { Sample } \\
\text { no. }\end{array}$ & $\begin{array}{l}\text { TVDss } \\
\text { (m) }\end{array}$ & $\begin{array}{l}\text { GRADISTAT } \\
\text { textural group }\end{array}$ & $\begin{array}{l}\text { Clay } \\
(<2 \mu \mathrm{m}) \\
(\%)\end{array}$ & $\begin{array}{l}\text { Silt } \\
(\%)\end{array}$ & $\begin{array}{l}\text { Clay to } \\
\text { fine silt } \\
(\%)\end{array}$ & $\begin{array}{l}\text { Sand } \\
(\%)\end{array}$ & $\begin{array}{l}\text { Porosity } \\
(\%)\end{array}$ & $\begin{array}{l}\text { Permeability } \\
\left(\mathrm{m}^{2}\right)\end{array}$ & $\begin{array}{l}\text { Hydraulic } \\
\text { conductivity } \\
\left(\mathrm{m} \mathrm{s}^{-1}\right)\end{array}$ \\
\hline \multirow[t]{3}{*}{ BUR-01 } & 570.8 & 646.06 & & & & & & & & & & \\
\hline & & & $\mathrm{XV}-1$ & 576.1 & sandy mud & 6.6 & 80.6 & & 12.8 & 25 & $1.9 \mathrm{E}-18$ & $1.9 \mathrm{E}-11$ \\
\hline & & & $X V-2$ & 641.6 & mud & & & 46.1 & 4.9 & 34 & $3.4 \mathrm{E}-19$ & 3.4E-12 \\
\hline \multirow[t]{3}{*}{ LW0-02 } & 590.69 & 674.51 & $\mathrm{XI}-1$ & 597 & mud & & & 38.5 & 6.1 & 32 & 4.9E-19 & $4.9 \mathrm{E}-12$ \\
\hline & & & XI-2 & 619 & mud & & & 42.1 & 4.0 & 33 & 4.1E-19 & $4.1 \mathrm{E}-12$ \\
\hline & & & XI-3 & 637 & mud & & & 40.0 & 1.9 & 32 & 4.2E-19 & 4.2E-12 \\
\hline \multirow[t]{10}{*}{ GRD-01 } & 446.07 & 570.81 & VIII-1 & 447.8 & mud & & & 46.1 & 0.3 & 38 & $6.8 \mathrm{E}-19$ & $6.8 \mathrm{E}-12$ \\
\hline & & & VIII-2 & 453.8 & mud & & & 45.0 & 0.0 & 37 & $6.9 \mathrm{E}-19$ & $6.9 \mathrm{E}-12$ \\
\hline & & & VIII-3 & 482.3 & mud & & & 45.2 & 0.1 & 37 & $6.1 \mathrm{E}-19$ & $6.1 \mathrm{E}-12$ \\
\hline & & & VIII-4 & 500.3 & mud & & & 46.5 & 0.2 & 37 & $5.4 \mathrm{E}-19$ & $5.4 \mathrm{E}-12$ \\
\hline & & & VIII-5 & 513.8 & mud & & & 47.3 & 0.2 & 37 & $5.0 \mathrm{E}-19$ & $5.0 \mathrm{E}-12$ \\
\hline & & & VIII-6 & 522.8 & mud & & & 43.5 & 0.3 & 35 & $5.5 \mathrm{E}-19$ & $5.5 \mathrm{E}-12$ \\
\hline & & & VIII-7 & 534.8 & mud & & & 40.2 & 3.8 & 33 & $5.8 \mathrm{E}-19$ & $5.8 \mathrm{E}-12$ \\
\hline & & & VIII-8 & 546.8 & mud & & & 40.9 & 2.5 & 34 & $5.5 \mathrm{E}-19$ & $5.5 \mathrm{E}-12$ \\
\hline & & & VIII-9 & 555.8 & mud & & & 42.9 & 2.4 & 34 & $5.0 \mathrm{E}-19$ & $5.0 \mathrm{E}-12$ \\
\hline & & & VIII-10 & 568.8 & mud & & & 39.3 & & 32 & 5.3E-19 & 5.3E-12 \\
\hline \multirow[t]{8}{*}{ ESG-01 } & 602.75 & 689.96 & XII-1 & 601.7 & sandy mud & 6.6 & 79.7 & & 13.7 & 25 & 2.0E-18 & $2.0-11$ \\
\hline & & & XII-2 & 611.7 & mud & & & 40.4 & 7.5 & 32 & $4.5 \mathrm{E}-19$ & $4 . .5 \mathrm{E}-12$ \\
\hline & & & XII-3 & 621.7 & mud & & & 36.7 & 8.3 & 30 & 4.7E-19 & 4..7E-12 \\
\hline & & & XII-4 & 631.7 & mud & & & 38.8 & 4.8 & 31 & 4.4E-19 & 4.4E-12 \\
\hline & & & XII-5 & 641.7 & mud & & & 37.7 & 2.2 & 31 & 4.3E-19 & 4.3E-12 \\
\hline & & & XII-6 & 651.7 & mud & & & 37.8 & 1.1 & 31 & 4.2E-19 & $4.2 \mathrm{E}-12$ \\
\hline & & & XII-7 & 661.7 & mud & & & 42.1 & 0.1 & 32 & $3.6 \mathrm{E}-19$ & 3..6E-12 \\
\hline & & & XII-8 & 671.7 & mud & & & 35.0 & 1.4 & 29 & 4.2E-19 & 4.2E-12 \\
\hline \multirow[t]{4}{*}{ EM0-01 } & 604.72 & 668.27 & XIV-1 & 611 & mud & & & 31.9 & 6.3 & 28 & $5.3 \mathrm{E}-19$ & $5.3 \mathrm{E}-12$ \\
\hline & & & XIV-2 & 623 & mud & & & 36.1 & 5.9 & 30 & 4.8E-19 & $4.8 \mathrm{E}-12$ \\
\hline & & & XIV-3 & 636 & mud & & & 33.6 & 4.1 & 29 & 4.8E-19 & 4.8E-12 \\
\hline & & & XIV-4 & 658 & mud & & & 40.4 & 0.5 & 32 & $3.9 \mathrm{E}-19$ & $3.9 \mathrm{E}-12$ \\
\hline
\end{tabular}


Table 1. Continued.

NORTHERN AREA

\begin{tabular}{|c|c|c|c|c|c|c|c|c|c|c|c|c|}
\hline Well name & $\begin{array}{l}\text { Top NMFRC }^{a} \\
\text { (mTVDss) }^{\mathrm{a}}\end{array}$ & $\begin{array}{l}\text { Bottom NMFRC } \\
\text { (mTVDss) }^{\mathrm{b}}\end{array}$ & $\begin{array}{l}\text { Sample } \\
\text { no. }\end{array}$ & $\begin{array}{l}\text { TVDss } \\
\text { (m) }\end{array}$ & $\begin{array}{l}\text { GRADISTAT } \\
\text { textural group }\end{array}$ & $\begin{array}{l}\text { Clay } \\
(<2 \mu \mathrm{m}) \\
(\%)\end{array}$ & $\begin{array}{l}\text { Silt } \\
(\%)\end{array}$ & $\begin{array}{l}\text { Clay to } \\
\text { fine silt } \\
(\%)\end{array}$ & $\begin{array}{l}\text { Sand } \\
(\%)\end{array}$ & $\begin{array}{l}\text { Porosity } \\
(\%)\end{array}$ & $\begin{array}{l}\text { Permeability } \\
\left(\mathrm{m}^{2}\right)\end{array}$ & $\begin{array}{l}\text { Hydraulic } \\
\text { conductivity } \\
\left(\mathrm{m} \mathrm{s}^{-1}\right)\end{array}$ \\
\hline \multirow[t]{10}{*}{ NNE-07 } & 427.98 & 538.64 & XIII-1 & 432 & mud & & & 46.5 & 0.9 & 38 & 7.2E-19 & 7.2E-12 \\
\hline & & & XIII-2 & 441.5 & mud & & & 41.7 & 3.8 & 36 & $8.0 \mathrm{E}-19$ & $8.0 \mathrm{E}-12$ \\
\hline & & & XIII-3 & 453 & mud & & & 38.1 & 2.6 & 34 & 8.3E-19 & 8.3E-12 \\
\hline & & & XIII-4 & 465 & mud & & & 50.4 & 0.4 & 40 & 5.4E-19 & 5.4E-12 \\
\hline & & & XIII-5 & 476.5 & mud & & & 48.6 & & 39 & $5.5 \mathrm{E}-19$ & $5.5 \mathrm{E}-12$ \\
\hline & & & XIII-6 & 488.5 & mud & & & 41.8 & 3.5 & 35 & $6.6 \mathrm{E}-19$ & $6.6 \mathrm{E}-12$ \\
\hline & & & XIII-7 & 503.5 & sandy mud & 9.1 & 79 & & 11.9 & 26 & 2.0E-18 & 2.0E-11 \\
\hline & & & XIII-8 & 513.5 & sandy mud & 9.5 & 63.1 & & 27.4 & 25 & $1.5 \mathrm{E}-17$ & $1.5 \mathrm{E}-10$ \\
\hline & & & XIII-9 & 522.5 & sandy mud & 8.6 & 58.1 & & 33.3 & 24 & $3.9 \mathrm{E}-17$ & $3.9 \mathrm{E}-10$ \\
\hline & & & XIII-10 & 537 & mud & & & 56.1 & 0.5 & 41 & 3.1E-19 & 3.1E-12 \\
\hline
\end{tabular}

NMRFC: Rupel Clay Member.

${ }^{b}$ mTVDss: metres true vertical depth below ground surface. 
Table 2. Calculated porosity and vertical permeability of the Rupel Clay Member in the southwest and southern area. Figure 2 shows the borehole locations.

\begin{tabular}{|c|c|c|c|c|c|c|c|c|c|c|c|c|}
\hline \multicolumn{13}{|c|}{ SOUTHWEST \& SOUTHERN AREA } \\
\hline Well name & $\begin{array}{l}\text { Top NMFRC }^{\mathrm{a}} \\
\text { (mTVDss) }^{\mathrm{b}}\end{array}$ & $\begin{array}{l}\text { Bottom NMFRC } \\
\text { (mTVDss) }^{\mathrm{b}}\end{array}$ & $\begin{array}{l}\text { Sample } \\
\text { no. }\end{array}$ & $\begin{array}{l}\text { TVDss } \\
\text { (m) }\end{array}$ & $\begin{array}{l}\text { GRADISTAT } \\
\text { textural rroup }\end{array}$ & $\begin{array}{l}\text { Clay } \\
(<2 \mu \mathrm{m}) \\
(\%)\end{array}$ & $\begin{array}{l}\text { Silt } \\
(\%)\end{array}$ & $\begin{array}{l}\text { Clay to } \\
\text { fine silt } \\
(\%)\end{array}$ & $\begin{array}{l}\text { Sand } \\
(\%)\end{array}$ & $\begin{array}{l}\text { Porosity } \\
(\%)\end{array}$ & $\begin{array}{l}\text { Permeability } \\
\left(\mathrm{m}^{2}\right)\end{array}$ & $\begin{array}{l}\text { Hydraulic } \\
\text { conductivity } \\
\left(\mathrm{m} \mathrm{s}^{-1}\right)\end{array}$ \\
\hline \multirow[t]{12}{*}{ B48G0159 } & 20.01 & 43.09 & IX-1 & 21 & mud & & & 51.8 & 1.7 & 60 & 7.7E-17 & $7.7 \mathrm{E}-10$ \\
\hline & & & IX-2 & 23 & mud & & & 45.2 & 1.7 & 56 & $6.5 \mathrm{E}-17$ & $6.5 \mathrm{E}-10$ \\
\hline & & & IX-3 & 25 & mud & & & 50.6 & 1.5 & 59 & $6.1 \mathrm{E}-17$ & $6.1 \mathrm{E}-10$ \\
\hline & & & IX-4 & 27 & mud & & & 48.7 & 5.2 & 57 & $5.4 \mathrm{E}-17$ & $5.4 \mathrm{E}-10$ \\
\hline & & & IX-5 & 29 & mud & & & 53.4 & 0.7 & 60 & 4.8E-17 & $4.8 \mathrm{E}-10$ \\
\hline & & & IX-6 & 31 & mud & & & 55.6 & 1.5 & 60 & $4.2 \mathrm{E}-17$ & 4.2E-10 \\
\hline & & & IX-7 & 33 & mud & & & 44.6 & 0.4 & 54 & 4.1E-17 & 4.1E-10 \\
\hline & & & IX-8 & 35 & sandy mud & 6.0 & 83.3 & & 10.7 & 52 & $1.2 \mathrm{E}-16$ & $1.2 \mathrm{E}-09$ \\
\hline & & & IX-9 & 37 & sandy mud & 5.2 & 82.4 & & 12.4 & 52 & $1.8 \mathrm{E}-16$ & $1.8 \mathrm{E}-09$ \\
\hline & & & IX-10 & 39 & sandy mud & 4.6 & 85.3 & & 10.1 & 52 & $1.2 \mathrm{E}-16$ & $1.2 \mathrm{E}-09$ \\
\hline & & & IX-11 & 41 & sandy mud & 4.1 & 81.4 & & 14.5 & 51 & 2.2E-16 & $2.2 \mathrm{E}-09$ \\
\hline & & & IX-12 & 43 & sandy mud & 7.2 & 69.8 & & 23.0 & 50 & $7.8 \mathrm{E}-16$ & 7.8E-09 \\
\hline \multirow[t]{5}{*}{ B49G0191 } & 79.12 & 84.37 & $\mathrm{X}-1$ & 79.9 & sandy mud & 5.9 & 83.4 & & 10.7 & 48 & $6.4 \mathrm{E}-17$ & $6.4 \mathrm{E}-10$ \\
\hline & & & $X-2$ & 80.9 & sandy mud & 5.2 & 80.2 & & 14.6 & 48 & $1.5 \mathrm{E}-16$ & $1.5 \mathrm{E}-09$ \\
\hline & & & $X-3$ & 81.9 & mud & & & 40.8 & 9.9 & 47 & $1.2 \mathrm{E}-17$ & $1.2 \mathrm{E}-10$ \\
\hline & & & $X-4$ & 82.9 & sandy mud & 9.5 & 48.1 & & 42.4 & 45 & $2.5 \mathrm{E}-14$ & $2.5 \mathrm{E}-07$ \\
\hline & & & $X-5$ & 84.7 & mud & & & 34.3 & 7.4 & 43 & $1.1 \mathrm{E}-17$ & $1.1 \mathrm{E}-10$ \\
\hline \multirow[t]{8}{*}{ B49G0959 } & 73.54 & 174.5 & VII-1 & 75.8 & mud & & & 16.8 & 6.9 & 31 & $8.6 \mathrm{E}-18$ & $8.6 \mathrm{E}-11$ \\
\hline & & & VII-2 & 87.8 & mud & & & 39.0 & 3.0 & 46 & $1.1 \mathrm{E}-17$ & $1.1 \mathrm{E}-10$ \\
\hline & & & VII-3 & 106.8 & mud & & & 32.3 & 1.5 & 40 & $8.0 \mathrm{E}-18$ & 8.0E-11 \\
\hline & & & VII-4 & 113.3 & mud & & & 43.8 & 2.5 & 47 & 7.2E-18 & 7.2E-11 \\
\hline & & & VII-5 & 128.8 & mud & & & 46.1 & 0.8 & 47 & $5.8 \mathrm{E}-18$ & $5.8 \mathrm{E}-11$ \\
\hline & & & VII-6 & 155.3 & sandy mud & 6.0 & 55 & & 39.0 & 38 & $1.5 \mathrm{E}-15$ & $1.5 \mathrm{E}-08$ \\
\hline & & & VII-7 & 162.8 & sandy mud & 4.2 & 64.2 & & 31.6 & 38 & 4.4E-16 & 4.4E-09 \\
\hline & & & VII-8 & 170.3 & sandy mud & 5.4 & 69.2 & & 25.4 & 38 & $1.6 \mathrm{E}-16$ & $1.6 \mathrm{E}-09$ \\
\hline
\end{tabular}


Table 2. Continued.

\begin{tabular}{|c|c|c|c|c|c|c|c|c|c|c|c|c|}
\hline \multicolumn{13}{|c|}{ SOUTHWEST \& SOUTHERN AREA } \\
\hline Well name & $\begin{array}{l}\text { Top NMFRC }^{\mathrm{a}} \\
\text { (mTVDss) }^{\mathrm{b}}\end{array}$ & $\begin{array}{l}\text { Bottom NMFRC } \\
\text { (mTVDss) }^{\mathrm{b}}\end{array}$ & $\begin{array}{l}\text { Sample } \\
\text { no. }\end{array}$ & $\begin{array}{l}\text { TVDss } \\
\text { (m) }\end{array}$ & $\begin{array}{l}\text { GRADISTAT } \\
\text { textural rroup }\end{array}$ & $\begin{array}{l}\text { Clay } \\
(<2 \mu \mathrm{m}) \\
(\%)\end{array}$ & $\begin{array}{l}\text { Silt } \\
(\%)\end{array}$ & $\begin{array}{l}\text { Clay to } \\
\text { fine silt } \\
(\%)\end{array}$ & $\begin{array}{l}\text { Sand } \\
(\%)\end{array}$ & $\begin{array}{l}\text { Porosity } \\
(\%)\end{array}$ & $\begin{array}{l}\text { Permeability } \\
\left(\mathrm{m}^{2}\right)\end{array}$ & $\begin{array}{l}\text { Hydraulic } \\
\text { conductivity } \\
\left(\mathrm{m} \mathrm{s}^{-1}\right)\end{array}$ \\
\hline \multirow[t]{11}{*}{ В50H0373 } & 319.49 & 472.02 & III-1 & 324.7 & sandy mud & 6.4 & 80.3 & & 13.3 & 31 & $5.8 \mathrm{E}-18$ & $5.8 \mathrm{E}-11$ \\
\hline & & & III-2 & 330.7 & sandy mud & 7.2 & 69.2 & & 23.6 & 29 & 2.2E-17 & $2.2 \mathrm{E}-10$ \\
\hline & & & III-3 & 348.2 & mud & & & 46.0 & 5.2 & 40 & $1.1 \mathrm{E}-18$ & $1.1 \mathrm{E}-11$ \\
\hline & & & III-4 & 365.7 & mud & & & 42.9 & 2.7 & 38 & $1.1 \mathrm{E}-18$ & $1.1 \mathrm{E}-11$ \\
\hline & & & III-5 & 382.2 & mud & & & 52.0 & & 42 & 7.4E-19 & 7.4E-12 \\
\hline & & & III-6 & 394.2 & mud & & & 38.4 & 1.6 & 35 & $1.1 \mathrm{E}-18$ & $1.1 \mathrm{E}-11$ \\
\hline & & & III-7 & 407.2 & mud & & & 41.3 & 1.6 & 36 & $9.4 \mathrm{E}-19$ & $9.4 \mathrm{E}-12$ \\
\hline & & & III-8 & 424.2 & mud & & & 42.4 & 1.7 & 37 & $8.5 \mathrm{E}-19$ & $8.5 \mathrm{E}-12$ \\
\hline & & & III-9 & 442.2 & mud & & & 34.6 & 4.0 & 32 & $9.2 \mathrm{E}-19$ & $9.2 \mathrm{E}-12$ \\
\hline & & & III-10 & 455.7 & sandy mud & 6.2 & 76 & & 17.8 & 27 & $6.4 \mathrm{E}-18$ & $6.4 \mathrm{E}-11$ \\
\hline & & & III-11 & 469.7 & sandy mud & 5.1 & 62.6 & & 32.3 & 26 & $6.0 \mathrm{E}-17$ & $6.0 \mathrm{E}-10$ \\
\hline
\end{tabular}

aNMRFC: Rupel Clay Member.

bmTVDs: metres true vertical depth below ground surface. 
Table 3. Calculated porosity and vertical permeability of the Rupel Clay Member in the east and southeastern area. Figure 2 shows the borehole locations.

EAST SOUTHEASTERN AREA

\begin{tabular}{|c|c|c|c|c|c|c|c|c|c|c|c|c|}
\hline Well name & $\begin{array}{l}\text { Top NMFRC }{ }^{\mathrm{a}} \\
\text { (mTVDss) }^{\mathrm{b}}\end{array}$ & $\begin{array}{l}\text { Bottom NMFRC } \\
\text { (mTVDss) }^{\mathrm{b}}\end{array}$ & $\begin{array}{l}\text { Sample } \\
\text { no. }\end{array}$ & $\begin{array}{l}\text { TVDss } \\
\text { (m) }\end{array}$ & $\begin{array}{l}\text { GRADISTAT } \\
\text { textural group }\end{array}$ & $\begin{array}{l}\text { Clay } \\
(<2 \mu \mathrm{m}) \\
(\%)\end{array}$ & $\begin{array}{l}\text { Silt } \\
(\%)\end{array}$ & $\begin{array}{l}\text { Clay to } \\
\text { fine silt } \\
(\%)\end{array}$ & $\begin{array}{l}\text { Sand } \\
(\%)\end{array}$ & $\begin{array}{l}\text { Porosity } \\
(\%)\end{array}$ & $\begin{array}{l}\text { Permeability } \\
\left(\mathrm{m}^{2}\right)\end{array}$ & $\begin{array}{l}\text { Hydraulic } \\
\text { conductivity } \\
\left(\mathrm{m} \mathrm{s}^{-1}\right)\end{array}$ \\
\hline \multirow[t]{12}{*}{ B41G0024 } & 1.97 & 107.91 & VI-1 & 6.75 & sandy mud & 5.0 & 70.4 & & 24.6 & 52 & $1.1 \mathrm{E}-15$ & $1.1 \mathrm{E}-08$ \\
\hline & & & VI-2 & 14.75 & sandy mud & 6.1 & 75.7 & & 18.2 & 52 & 4.9E- 16 & $4.9 \mathrm{E}-09$ \\
\hline & & & VI-3 & 22 & sandy mud & 9.4 & 78.9 & & 11.7 & 53 & $1.7 \mathrm{E}-16$ & $1.7 \mathrm{E}-09$ \\
\hline & & & VI-4 & 29.5 & sandy mud & 4.7 & 81.5 & & 13.8 & 52 & $2.1 \mathrm{E}-16$ & 2.1E-09 \\
\hline & & & VI-5 & 37.25 & sandy mud & 6.4 & 81.2 & & 12.4 & 51 & $1.4 \mathrm{E}-16$ & $1.4 \mathrm{E}-09$ \\
\hline & & & VI-6 & 46.25 & sandy mud & 10.1 & 71 & & 18.9 & 49 & $3.2 \mathrm{E}-16$ & $3.2 \mathrm{E}-09$ \\
\hline & & & VI-7 & 56.75 & mud & & & 45.8 & 3.7 & 52 & $1.9 \mathrm{E}-17$ & $1.9 \mathrm{E}-10$ \\
\hline & & & VI-8 & 67.75 & mud & & & 36.6 & 7.6 & 46 & $1.5 \mathrm{E}-17$ & $1.5 \mathrm{E}-10$ \\
\hline & & & VI-9 & 78.25 & mud & & & 47.8 & 1.9 & 51 & $1.2 \mathrm{E}-17$ & $1.2 \mathrm{E}-10$ \\
\hline & & & VI-10 & 86.25 & mud & & & 49.0 & 1.1 & 51 & $1.0 \mathrm{E}-17$ & $1.0 \mathrm{E}-10$ \\
\hline & & & VI-11 & 96 & mud & & & 44.8 & 3.8 & 49 & $9.1 \mathrm{E}-18$ & $9.1 \mathrm{E}-11$ \\
\hline & & & VI-12 & 104.75 & mud & & & 38.0 & 4.7 & 44 & $8.4 \mathrm{E}-18$ & 8.4E-11 \\
\hline \multirow[t]{11}{*}{ B46C0478 } & 132.69 & 345.61 & $\mathrm{~V}-1$ & 135.3 & sandy mud & 7.2 & 76.5 & & 16.3 & 42 & $5.8 \mathrm{E}-17$ & $5.8 \mathrm{E}-10$ \\
\hline & & & V-2 & 150.3 & sandy mud & 6.1 & 77.1 & & 16.8 & 40 & $5.1 \mathrm{E}-17$ & $5.1 \mathrm{E}-10$ \\
\hline & & & $V-3$ & 165.3 & sandy mud & 4.8 & 83 & & 12.2 & 40 & $2.4 \mathrm{E}-17$ & $2.4 \mathrm{E}-10$ \\
\hline & & & V-4 & 178.3 & mud & & & 37.0 & 4.5 & 40 & $3.9 \mathrm{E}-18$ & $3.9 \mathrm{E}-11$ \\
\hline & & & V-5 & 195.3 & mud & & & 47.2 & & 45 & $2.9 \mathrm{E}-18$ & $2.9 \mathrm{E}-11$ \\
\hline & & & V-6 & 208.3 & mud & & & 55.3 & 0.3 & 49 & $2.0 \mathrm{E}-18$ & $2.0 \mathrm{E}-11$ \\
\hline & & & $\mathrm{V}-7$ & 222.3 & mud & & & 46.6 & 2.4 & 44 & $2.4 \mathrm{E}-18$ & $2.4 \mathrm{E}-11$ \\
\hline & & & V-8 & 234.3 & mud & & & 40.6 & 5.6 & 40 & $2.5 \mathrm{E}-18$ & $2.5 \mathrm{E}-11$ \\
\hline & & & V-9 & 262.3 & mud & & & 39.9 & 6.9 & 39 & $2.1 \mathrm{E}-18$ & $2.1 \mathrm{E}-11$ \\
\hline & & & $\mathrm{V}-10$ & 294.3 & muddy sand & 4.2 & 19.5 & & 76.3 & 28 & $2.0 \mathrm{E}-13$ & $2.0 \mathrm{E}-06$ \\
\hline & & & $\mathrm{V}-11$ & 312.3 & sandy mud & 5.5 & 73.3 & & 21.2 & 30 & $2.0 \mathrm{E}-17$ & $2.0 \mathrm{E}-10$ \\
\hline
\end{tabular}


Table 3. Continued.

\begin{tabular}{|c|c|c|c|c|c|c|c|c|c|c|c|c|}
\hline \multicolumn{13}{|c|}{ EAST SOUTHEASTERN AREA } \\
\hline Well name & $\begin{array}{l}\text { Top NMFRC }{ }^{\mathrm{a}} \\
\text { (mTVDss) }^{\mathrm{b}}\end{array}$ & $\begin{array}{l}\text { Bottom NMFRC } \\
\text { (mTVDss) }^{\mathrm{b}}\end{array}$ & $\begin{array}{l}\text { Sample } \\
\text { no. }\end{array}$ & $\begin{array}{l}\text { TVDss } \\
(\mathrm{m})\end{array}$ & $\begin{array}{l}\text { GRADISTAT } \\
\text { textural group }\end{array}$ & $\begin{array}{l}\text { Clay } \\
(<2 \mu \mathrm{m}) \\
(\%)\end{array}$ & $\begin{array}{l}\text { Silt } \\
(\%)\end{array}$ & $\begin{array}{l}\text { Clay to } \\
\text { fine silt } \\
(\%)\end{array}$ & $\begin{array}{l}\text { Sand } \\
(\%)\end{array}$ & $\begin{array}{l}\text { Porosity } \\
(\%)\end{array}$ & $\begin{array}{l}\text { Permeability } \\
\left(\mathrm{m}^{2}\right)\end{array}$ & $\begin{array}{l}\text { Hydraulic } \\
\text { conductivity } \\
\left(\mathrm{m} \mathrm{s}^{-1}\right)\end{array}$ \\
\hline \multirow[t]{11}{*}{ B52E0114 } & 364.7 & 526.7 & II-1 & 380.95 & sandy mud & 7.5 & 52.9 & & 39.6 & 27 & $2.1 \mathrm{E}-16$ & $2.1 \mathrm{E}-09$ \\
\hline & & & II-2 & 398.45 & sandy mud & 7.2 & 54.2 & & 38.6 & 27 & $1.9 \mathrm{E}-16$ & $1.9 \mathrm{E}-09$ \\
\hline & & & II-3 & 418.45 & mud & & & 41.4 & 9.7 & 36 & $8.9 \mathrm{E}-19$ & $8.9 \mathrm{E}-12$ \\
\hline & & & II-4 & 436.2 & mud & & & 63.3 & & 46 & $3.0 \mathrm{E}-19$ & $3.0 \mathrm{E}-12$ \\
\hline & & & II-5 & 443.7 & mud & & & 70.7 & & 49 & $1.6 \mathrm{E}-19$ & $1.6 \mathrm{E}-12$ \\
\hline & & & II-6 & 460.35 & sandy mud & 13.5 & 70.3 & & 16.2 & 28 & $4.6 \mathrm{E}-18$ & 4.6E-11 \\
\hline & & & II-7 & 479.2 & mud & & & 49.9 & 1.9 & 39 & $5.2 \mathrm{E}-19$ & $5.2 \mathrm{E}-12$ \\
\hline & & & II-8 & 491.45 & mud & & & 60.5 & 0.4 & 44 & $2.9 \mathrm{E}-19$ & $2.9 \mathrm{E}-12$ \\
\hline & & & II-9 & 504.95 & mud & & & 47.8 & & 38 & $5.1 \mathrm{E}-19$ & $5.1 \mathrm{E}-12$ \\
\hline & & & II-10 & 518.45 & muddy sand & 11.2 & 31.9 & & 56.9 & 23 & $8.4 \mathrm{E}-16$ & $8.4 \mathrm{E}-09$ \\
\hline & & & II-11 & 523.7 & muddy sand & 3.9 & 13.9 & & 82.2 & 23 & $4.6 \mathrm{E}-14$ & 4.6E-07 \\
\hline
\end{tabular}

${ }^{a}$ NMRFC: Rupel Clay Member.

${ }^{b}$ mTVDss: metres true vertical depth below ground surface. 